\title{
In vitro Regeneration of Japanese Burdock (Arctium lappa L.) from Cotyledon and Leaf Derived Explants
}

\section{Mustafa Abul Kalam Azad*, Md. Arifuzzaman, Md. Mobarok Hossain, Md. Sohel Arman and Muhammad Nurul Amin}

Department of Botany, University of Rajshahi, Rajshahi-6205, Bangladesh

Keywords: Arctium lappa, Medicinal plant, Shoot regeneration, Plant growth regulators, Root vegetable, Acclimatization

\begin{abstract}
Considering the vegetable and medicinal values, a micropropagation protocol has been established for Japanese Burdock (Arctium lappa L.) by culturing the explants of cotyledon and leaf obtained from in vitro grown seedlings. Direct shoot regeneration was achieved from cotyledon and leaf explants on MS fortified with 4.0 $\mu \mathrm{M}$ BAP and 2.0 $\mu \mathrm{M}$ IBA or NAA after 5 weeks of culture. In addition, both the explants also formed callus from their cut margins within 6 weeks of cultivation on medium complemented with 6.0 $\mu \mathrm{M}$ BAP and 4.0 $\mu \mathrm{M}$ IBA or NAA. Adventitious shoots were also redeveloped through indirect organogenesis from the cotyledon and leaf-derived callus within 10 weeks of culture on MS containing 4.0 $\mu \mathrm{M}$ BAP and $2.0 \mu \mathrm{M}$ IBA or NAA. The highest rate of shoot reproduction was attained at the third subculture, and more than 12.6 shoots were formed per callus clump. Within 4 weeks of transfer to the rooting medium on MS containing $6.0 \mu \mathrm{M}$ IBA, the cultured micro-shoots produced highest 5.3 roots per cultured shoot. Rooted plantlets were successfully established on a soil-composed-sand mixture under natural condition with $93.3 \%$ survival rate
\end{abstract}

\section{Introduction}

Arctium lappa, commonly called greater burdock, gobō, edible burdock, or happy major belongs to the Compositae family. This species is a native to the temperate regions of the countries from Scandinavian to the Mediterranean, and the Middle Eastern to China, Taiwan and Japan (Rose 1981). The great burdock is a biennial plant and its height is up to a maximum $3.0 \mathrm{~m}$. This plant has dark green leaves which will get older to $70 \mathrm{~cm}$ long. Leaves are heart-shaped and that they are commonly large, coarse and ovate. they're woolly underneath and therefore the leafstalks are generally hollow. Burdock flowers are

*Author for correspondence: <drmakazad@gmail.com>. 
purple and congregated in spherical capitula, appear in July to September. The fleshy burdock taproot can get older to $1 \mathrm{~m}$ deep (Grieve 1971, Cole et al. 2016). This root is known as niúbàng in Chinese, which was borrowed into Japanese as gobō and Korean as ueong, and is widely eaten as vegetable in Japan, Korea and Taiwan. The powder of the dried burdock root is used as a aqua-drinks in human remedies as a diuretic, diaphoretic, and a blood cleanser. Unreliable reviews from the nineteenth century advise that this medicinal plant has additionally been hired through the Ojibwa tribe, and today, in a form of tea component for the selective remedy of cancers. The oily macerate of the root powder can be used in some cosmetics, shampoos and hair care products as well. Burdock seeds are used in Chinese conventional medicines that dissipates air heat, releases toxins, moisturizes the intestines and relieves irritation. The seeds are also effective for its antibiotic, antidiabetic, and antipyretic effects till the second half of the twentieth century. The fresh root of the plant has a reputation for its culinary use as delicious vegetable dishes. The root contains a good amount of dietary fiber (GDF, $6 \mathrm{~g}$ per 100g), calcium, potassium, amino acids, and is low in calorific value. (Matsumoto et al. 2006, Chan et al. 2010, Ferracane et al. 2010, Imahori et al. 2010). In pharmaceutical industries, there are many reports of A. lappa as medicinal uses (Liu et al. 2005, Lou et al. 2010A, 2010B). But there are very few reports on tissue culture of this medicinally important plant. HE et al. (2006) reported a protocol for callus induction and plant regeneration from hypocotyl and cotyledon explants of A. lappa. Zebarjadi et al. developed a protocol for in vitro cell differentiation and multiplication of Burdock. Another regeneration system of Burdock using different explants was also described by Wenting et al. (2006).

During the present study, we have described a high frequency plant regeneration protocol for A. lappa from cotyledon and leaf explants, both using direct and indirect regeneration methods. The main objective of our study is to develop a new suitable line through somaclonal variation that can be grown in Bangladeshi climate. Our farmers may cultivate this medicinally important vegetable plant for local consumptions. The plant can also be made as an export item for earning foreign currency as the plant has huge medicinal and culinary demands in countries like China, Taiwan and Japan.

\section{Materials and Methods}

The seeds of Arctium lappa, had been accumulated from Japan through online shopping, e-Bay and were used as the experimental materials. For raising/growing aseptic seedlings, seeds had been washed very well under running tap water for ten mins to lessen the extent of surface microorganisms. Surface sterilization of the seeds was done following treatment of seeds with 1\% Savlon (3\% Cetrimide, an antiseptic plus detergent, marketed in Bangladesh by ICI Bangladesh Ltd.) for 10 min with continuous shaking, second washing with uninterruptedly tap water to make the material free from Savlonfoam and lastly washing sensibly 2-3 times with distilled water. The seeds were then 
taken under running laminar airflow cabinet and transferred to $250 \mathrm{ml}$ sterilized conical flask. After rinsing in $80 \%$ ethanol, they were engrossed in $0.1 \% \mathrm{HgCl}_{2}$ for different duration of time. For breaking dormancy, the seeds were incubated in $50{ }^{\circ} \mathrm{C}$ water for 2 min. After washing with double sterile distilled water, the seeds were spread over the surface of semisolid MS. The aseptic seedlings reached a height of 5-6 cm after 20-30 days of cultivation.

The explants entailing of cotyledon and in vitro grown leaf were prepared from the aseptically grown six-week-old seedlings. They were then cultivated on agar-gelled MS complemented with 2.0-6.0 $\mu \mathrm{M}$ BAP along with 1.0-4.0 $\mu \mathrm{M}$ of either IBA or NAA for direct adventitious shoots. Concurrently, cotyledon and leaf-derived callus were also cultured on MS containing 2.0-6.0 $\mu \mathrm{M}$ BAP, Kn or TDZ accompanied with 1.0-4.0 $\mu \mathrm{M}$ IBA or NAA for restoring adventitious shoots. The microshoots accumulated from in vitro grown shoot clusters were rooted in full strength as well as half strength of MS media supplemented with rooting hormones and 3\% sucrose. The rooting media were also gelled with $0.8 \%$ agar (Hi-media, India). All media were adjusted to $\mathrm{pH} 5.7 \pm 0.1$ and steam sterilized for $20 \mathrm{~min}$ at $121^{\circ} \mathrm{C}$ under $1.2 \mathrm{~kg} / \mathrm{cm}^{2}$ pressure.

The cultures were grown at $25 \pm 1{ }^{\circ} \mathrm{C}$ under the lighting of cool-white fluorescence tubular lamp with a light intensity of $50 \mu \mathrm{mol} \cdot \mathrm{m}^{-2} \cdot \mathrm{s}^{-1}$ for a $16 \mathrm{hrs}$. photoperiod. Well rooted fifty plantlets were separated from the test tubes and their roots were washed in tap water. Then the material was transplanted into small plastic pot filled with different substrates e.g. garden-soil, garden-soil:sand:compost (2:1:1) and vermicompost, covered with clear plastic bag. The plants were kept under culture room condition and watered daily to maintain high moisture Subsequently, the plastic pots were transferred to a shaded place in outdoor condition with regular irrigation. After 15 days, the potting plants were transferred to beds filled with garden-soil and cattle manure, in the proportion $2: 1(\mathrm{~N} / \mathrm{N})$ and irrigated regularly.

\section{Results and Discussion}

Seedling derived cotyledon and leaf explants were cultured on MS augmented with different concentrations of BAP alone and in combinations of IBA or NAA for inducing direct adventitious shoot regeneration. The information on percent of shoot formation, intensity of callus growth, and number of total shoots per culture from different treatments were recorded after 10 weeks of culture initiation. Results acquired on morphogenic responses of the cultured explants are presented in Table 1. BAP alone in the medium produced low percentages $(13-40 \%)$ of adventitious shoots, without any amount of morphogenic or non-morphogenic callus. Out of the three BAP-IBA combinations, the medium containing $4.0 \mu \mathrm{M}$ BAP with $2.0 \mu \mathrm{M}$ IBA produced the highest 87.0 and 75.0 percentages of shoots from cotyledon and leaf explants, respectively

also without forming of any callus (Figure 1A-B). In this combination maximum number shoots were obtained from the cotyledon and leaf explants, $6.0 \pm 0.1 \%$ and $5.5 \pm 0.5 \%$ 
respectively. On the other hand, among the combinations of BAP-NAA maximum frequency of 73.0 and 60.0 percentage direct shoot bud formation were observed in 4.0 $\mu \mathrm{M}$ BAP with $2.0 \mu \mathrm{M}$ NAA containing medium where the maximum $4.2 \pm 0.6$ and $3.8 \pm$ 0.3 shoots per cultures were recorded from cotyledon and leaf explants, respectively. In this experiment $6.0 \mu \mathrm{M}$ of BAP with $4.0 \mu \mathrm{M}$ of IBA or NAA produced considerable callusing. In the present study, organogenic and non organogenic callus formation was significantly dependent on the culture media composition and type of explants used.

Table 1. Effects of different concentrations of cytokinin alone and in combinations with auxins on induction of direct adventitious shoots from cotyledon and leaf explants.

\begin{tabular}{|c|c|c|c|c|c|c|}
\hline \multirow{2}{*}{$\begin{array}{l}\text { Growth } \\
\text { regulators } \\
(\mu \mathrm{M})\end{array}$} & \multicolumn{3}{|c|}{ Cotyledon } & \multicolumn{3}{|c|}{ Leaf } \\
\hline & $\begin{array}{l}\text { Shoot formation } \\
(\%)\end{array}$ & $\begin{array}{l}\text { *Intensity of } \\
\text { callus growth }\end{array}$ & $\begin{array}{l}\text { No. of total } \\
\text { shoot/culture }\end{array}$ & $\begin{array}{c}\text { Shoot } \\
\text { formation }(\%)\end{array}$ & $\begin{array}{l}\text { *Intensity of } \\
\text { callus growth }\end{array}$ & $\begin{array}{l}\text { No. of total } \\
\text { shoot/culture }\end{array}$ \\
\hline \multicolumn{7}{|l|}{ BAP } \\
\hline 2.0 & 13.0 & - & $1.3 \pm 0.3 e$ & 10.0 & - & $1.1 \pm 0.4 \mathrm{~g}$ \\
\hline 4.0 & 40.0 & - & $3.2 \pm 0.5 c$ & 30.0 & - & $2.5 \pm 0.2 d$ \\
\hline 6.0 & 33.0 & - & $1.5 \pm 0.2 \mathrm{e}$ & 20.0 & - & $1.3 \pm 0.5 f$ \\
\hline \multicolumn{7}{|l|}{$\mathrm{BAP}+\mathrm{IBA}$} \\
\hline $2.0+1.0$ & 53.0 & - & $3.5 \pm 0.4 \mathrm{c}$ & 45.0 & - & $4.6 \pm 0.4 b$ \\
\hline $4.0+2.0$ & 87.0 & - & $6.0 \pm 0.1 \mathrm{a}$ & 75.0 & - & $5.5 \pm 0.5 \mathrm{a}$ \\
\hline $6.0+4.0$ & 60.0 & + & $4.3 \pm 0.2 b$ & 50.0 & + & $3.5 \pm 0.2 \mathrm{c}$ \\
\hline \multicolumn{7}{|l|}{$\mathrm{BAP}+\mathrm{NAA}$} \\
\hline $2.0+1.0$ & 33.0 & - & $2.5 \pm 0.2 c$ & 25.0 & - & $1.9 \pm 0.5 \mathrm{e}$ \\
\hline $4.0+2.0$ & 73.0 & - & $4.2 \pm 0.6 b$ & 60.0 & - & $3.8 \pm 0.3 c$ \\
\hline $6.0+4.0$ & 40.0 & + & $3.1 \pm 0.3 c$ & 35.0 & + & $2.7 \pm 0.2 \mathrm{~d}$ \\
\hline
\end{tabular}

*Intensity of callusing: (+) considerable callusing, (-) no callusing. Values represent means \pm standard error of 15 explants per treatment. Means followed by the same letters are not significantly different by Duncan's multiple Range Test at $0.05 \%$ probability level.

The frequencies among adventitious shoot formation from the callus cultures were significantly different (Table 2). Among the different treatments, MS fortified with 4.0 $\mu \mathrm{M}$ BAP plus $2.0 \mu \mathrm{M}$ IBA produced adventitious shoots at high rate, and the frequencies were $93.0 \%$ and $80.0 \%$ respectively from the cotyledon and leaf-derived callus cultures. Substantial amount shoot formation was achieved from the explants of A. lappa on 4.0 $\mu \mathrm{M}$ BAP and 2.0 $\mu \mathrm{M}$ NAA supplemented MS. The lowest frequencies of adventitious shoot formation from cotyledon and leaf-derived callus were obtained in MS augmented with $6.0 \mu \mathrm{M} \mathrm{Kn}$ and $4.0 \mu \mathrm{M}$ IBA or NAA. Determination of the optimal types and concentrations of plant growth regulators as medium supplements is one of the leading important aspects of successful plant regeneration in vitro (Shimizu-Sato et al. 2009). The 
excessive concentration of cytokinin and auxin combination did not produce high frequencies of adventitious shoots however, that combination produced huge quantities of morphogenic or non-morphogenic callus. In this test it turned into determined that 4.0 $\mu \mathrm{M}$ BAP as cytokinin with $2.0 \mu \mathrm{M}$ IBA as auxin turned into the satisfactory media combos for proliferation of the adventitious shoots from each the cotyledon and leafderived callus. Callus appeared on the cut margins and thereafter covered the entire surface of the responsive explants cultured on medium with plant growth regulators after a culture initiation of 4 weeks and 8 weeks, respectively (Fig. 1C-E).

Table 2. Effects of different concentrations and combinations of cytokinins and auxins on induction of adventitious shoots from cotyledon and leaf-derived callus.

\begin{tabular}{|c|c|c|c|c|c|c|}
\hline \multirow{2}{*}{$\begin{array}{l}\text { Growth } \\
\text { regulators } \\
(\mu \mathrm{M})\end{array}$} & \multicolumn{3}{|c|}{ Cotyledon } & \multicolumn{3}{|c|}{ Leaf } \\
\hline & $\begin{array}{c}\text { Shoot } \\
\text { formation } \\
(\%)\end{array}$ & $\begin{array}{l}\text { *Intensity } \\
\text { of callus } \\
\text { growth }\end{array}$ & $\begin{array}{c}\text { No. of total } \\
\text { shoot/culture }\end{array}$ & $\begin{array}{c}\text { Shoot } \\
\text { Formation }(\%)\end{array}$ & $\begin{array}{l}\text { *Intensity } \\
\text { of callus } \\
\text { growth }\end{array}$ & $\begin{array}{l}\text { No. of total } \\
\text { shoot/culture }\end{array}$ \\
\hline \multicolumn{7}{|l|}{$\mathrm{BAP}+\mathrm{IBA}$} \\
\hline $2.0+1.0$ & 73.0 & + & $7.5 \pm 0.4 \mathrm{c}$ & 67.0 & + & $5.6 \pm 0.4 c$ \\
\hline $4.0+2.0$ & 93.0 & H & $12.6 \pm 0.1 \mathrm{a}$ & 80.0 & H & $10.2 \pm 0.5 \mathrm{a}$ \\
\hline $6.0+4.0$ & 60.0 & H & $6.5 \pm 0.2 d$ & 53.0 & H & $4.2 \pm 0.2 \mathrm{~d}$ \\
\hline \multicolumn{7}{|l|}{$\mathrm{BAP}+\mathrm{NAA}$} \\
\hline $2.0+1.0$ & 53.0 & + & $6.5 \pm 0.2 d$ & 47.0 & + & $4.7 \pm 0.5 \mathrm{~d}$ \\
\hline $4.0+2.0$ & 80.0 & + & $9.0 \pm 0.6 b$ & 73.0 & ++ & $7.6 \pm 0.3 b$ \\
\hline $6.0+4.0$ & 40.0 & H+ & $5.2 \pm 0.3 e$ & 33.0 & H+ & $3.5 \pm 0.2 \mathrm{~d}$ \\
\hline \multicolumn{7}{|l|}{$\mathrm{Kn}+\mathrm{IBA}$} \\
\hline $2.0+1.0$ & 27.0 & + & $4.0 \pm 0.4 \mathrm{f}$ & 33.0 & + & $2.9 \pm 0.4 \mathrm{~d}$ \\
\hline $4.0+2.0$ & 60.0 & + & $5.5 \pm 0.1 \mathrm{e}$ & 53.0 & + & $3.8 \pm 0.5 \mathrm{~d}$ \\
\hline $6.0+4.0$ & 20.0 & H & $2.6 \pm 0.2 \mathrm{gh}$ & 13.0 & H & $2.1 \pm 0.2 \mathrm{~d}$ \\
\hline \multicolumn{7}{|l|}{$\mathrm{Kn}+\mathrm{NAA}$} \\
\hline $2.0+1.0$ & 13.0 & + & $3.1 \pm 0.2 \mathrm{~g}$ & 7.0 & + & $2.2 \pm 0.5 \mathrm{~d}$ \\
\hline $4.0+2.0$ & 40.0 & ++ & $4.6 \pm 0.6 f$ & 33.0 & ++ & $3.1 \pm 0.3 \mathrm{~d}$ \\
\hline $6.0+4.0$ & 7.0 & + & $2.1 \pm 0.3 \mathrm{hi}$ & 0.0 & + & - \\
\hline \multicolumn{7}{|l|}{$\mathrm{TDZ}+\mathrm{IBA}$} \\
\hline $2.0+1.0$ & 40.0 & + & $4.2 \pm 0.1 \mathrm{f}$ & 33.0 & + & $3.6 \pm 0.4 \mathrm{~d}$ \\
\hline $4.0+2.0$ & 73.0 & H & $6.4 \pm 0.3 \mathrm{~d}$ & 67.0 & H & $4.5 \pm 0.5 \mathrm{~d}$ \\
\hline $6.0+4.0$ & 33.0 & H+ & $3.1 \pm 0.1 \mathrm{~g}$ & 27.0 & H+ & $2.7 \pm 0.2 \mathrm{~d}$ \\
\hline \multicolumn{7}{|c|}{$\mathrm{TDZ}+\mathrm{NAA}$} \\
\hline $2.0+1.0$ & 33.0 & + & $3.5 \pm 0.4 \mathrm{fg}$ & 27.0 & + & $2.6 \pm 0.5 \mathrm{~d}$ \\
\hline $4.0+2.0$ & 60.0 & + & $5.5 \pm 0.6 \mathrm{e}$ & 53.0 & + & $4.2 \pm 0.3 d$ \\
\hline $6.0+4.0$ & 27.0 & H+ & $2.6 \pm 0.3 \mathrm{gh}$ & 2.0 & H+ & $2.1 \pm 0.2 d$ \\
\hline
\end{tabular}

*Intensity of callusing: (+) slight callusing, (+) considerable callusing, (+++) intensive callusing and (-) no callusing. Values represent means \pm standard error of 15 explants per treatment. Means followed by the same letters are not significantly different by Duncan's multiple Range Test at $0.05 \%$ probability level. 

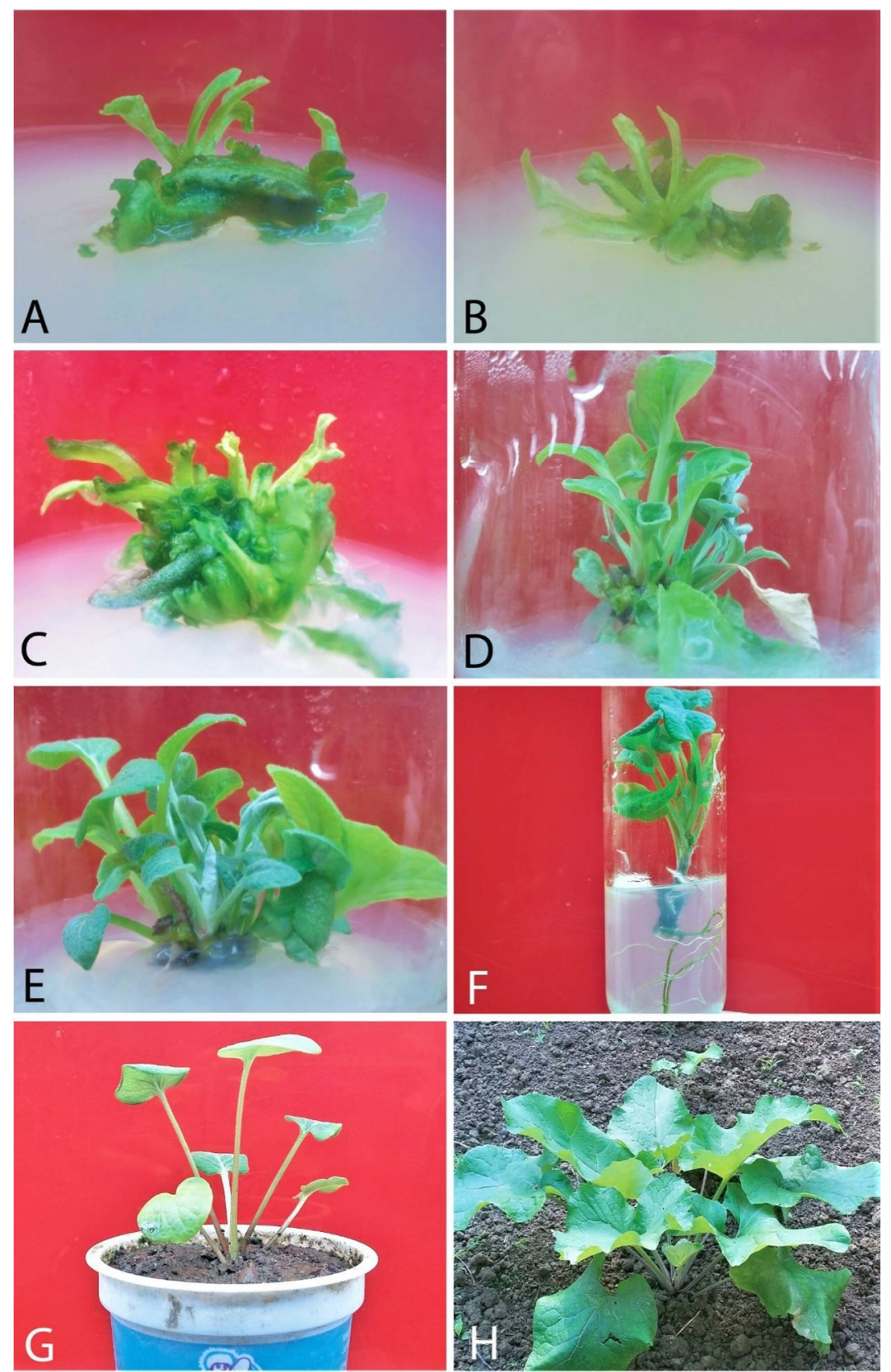

Fig. 1. Plant regeneration and acclimatization of A. lappa. A-B. Direct adventitious shoot developed from the cut margin of cotyledon (A) and leaf (B) explants on MS containing 4.0 $\mu \mathrm{M}$ BAP and $2.0 \mu \mathrm{M}$ IBA after 6 weeks of culture incubation. C-D. Proliferation of callus and development of adventitious shoots from cotyledon (C) and leaf (D) derived callus on the same medium after 6 weeks and 8 weeks of culture incubation. E. Elongation and multiplication of adventitious shoots after 10 weeks of culture incubation. F. Rooting of the in vitro proliferated shoots. G-H. Regenerated plantlet on soil after 3 weeks (G) and 12 weeks of transfer under ex vitro condition. 
Successful development of plantlets depends on the fruitful establishment of the proliferated shoots in the soil. For this reason, microshoots collected from the in vitro multiplied shoot clusters were rooted on MS and $1 / 2 \mathrm{MS}$ media separately with different strengths $(4.0-8.0 \mu \mathrm{M})$ of auxins (IBA, NAA and IAA) sepately. Our experiments revealed that among the two strengths of MS, full strength MS was the best for root formation medium in A. lappa (Table 3). The maximum percentage of root formation $(100 \%)$ was found in $6.0 \mu \mathrm{M}$ IBA supplemented MS, whereas, $93 \%$ root formation occurred in MS media containing 4.0 $\mu \mathrm{M}$ NAA (Fig. 1F). On the other hand, highest $80 \%$ root formation was observed with $6.0 \mu \mathrm{M}$ IBA containing $1 / 2 \mathrm{MS}$. The highest number $5.3 \pm$ 0.4 of roots and the maximum length $15.6 \pm 0.2 \mathrm{~cm}$ of the longest root per shoot were

Table 3. Effects of different concentrations of various auxins in MS and $1 / 2$ MS media on adventitious root formation from A. lappa microcuttings.

\begin{tabular}{|c|c|c|c|c|c|c|}
\hline $\begin{array}{l}\text { Media and } \\
\text { types of auxins }\end{array}$ & $\begin{array}{c}\text { Conc. of } \\
\text { auxins } \\
(\mu \mathrm{M})\end{array}$ & $\begin{array}{c}\text { Root } \\
\text { formation } \\
(\%)\end{array}$ & $\begin{array}{c}\text { No of roots/ } \\
\text { rooted } \\
\text { cutting }\end{array}$ & $\begin{array}{l}\text { Average } \\
\text { length of } \\
\text { roots }(\mathrm{cm})\end{array}$ & $\begin{array}{c}\text { Days to } \\
\text { root } \\
\text { formation }\end{array}$ & $\begin{array}{l}\text { Callus } \\
\text { formation at } \\
\text { the cutting base }\end{array}$ \\
\hline \multirow[t]{3}{*}{ MS+IBA } & 4.0 & 93.0 & $3.5 \pm 0.2 b$ & $12.5 \pm 0.1 b$ & $7-10$ & - \\
\hline & 6.0 & 100.0 & $5.3 \pm 0.4 a$ & $15.6 \pm 0.2 \mathrm{a}$ & $8-12$ & - \\
\hline & 8.0 & 87.0 & $2.5 \pm 0.1 \mathrm{c}$ & $8.7 \pm 0.4 \mathrm{a}$ & $10-12$ & H \\
\hline \multirow[t]{3}{*}{ MS+NAA } & 4.0 & 93.0 & $2.6 \pm 0.3 c$ & $10.8 \pm 0.7 \mathrm{c}$ & $7-10$ & - \\
\hline & 6.0 & 87.0 & $5.1 \pm 0.5 a$ & $12.2 \pm 0.1 b$ & $9-12$ & + \\
\hline & 8.0 & 80.0 & $1.7 \pm 0.1 \mathrm{c}$ & $6.5 \pm 0.1 \mathrm{f}$ & $10-15$ & + \\
\hline \multirow[t]{3}{*}{ MS + IAA } & 4.0 & 27.0 & $1.9 \pm 0.3 c$ & $4.8 \pm 0.7 \mathrm{~g}$ & $12-15$ & - \\
\hline & 6.0 & 53.0 & $2.7 \pm 0.2 c$ & $6.3 \pm 0.2 f$ & $10-15$ & - \\
\hline & 8.0 & 60.0 & $1.2 \pm 0.3 c$ & $3.2 \pm 0.1 \mathrm{f}$ & $10-15$ & - \\
\hline \multirow[t]{3}{*}{ 1/2MS+IBA } & 4.0 & 73.0 & $2.9 \pm 0.2 c$ & $8.3 \pm 0.1 d$ & $10-15$ & - \\
\hline & 6.0 & 80.0 & $3.8 \pm 0.4 b$ & $10.5 \pm 0.3 c$ & $8-15$ & + \\
\hline & 8.0 & 67.0 & $1.7 \pm 0.2 c$ & $6.1 \pm 0.5 f$ & $10-15$ & H \\
\hline \multirow[t]{3}{*}{$1 / 2 \mathrm{MS}+\mathrm{NAA}$} & 4.0 & 60.0 & $2.2 \pm 0.2 \mathrm{c}$ & $5.3 \pm 0.2 \mathrm{~g}$ & $10-12$ & - \\
\hline & 6.0 & 73.0 & $3.1 \pm 0.3 b c$ & $7.2 \pm 0.3 \mathrm{e}$ & $10-15$ & + \\
\hline & 8.0 & 53.0 & $1.5 \pm 0.4 c$ & $4.4 \pm 0.3 \mathrm{~g}$ & $12-18$ & + \\
\hline \multirow[t]{3}{*}{ 1/2MS+IAA } & 4.0 & 20.0 & $1.1 \pm 0.2 c$ & $3.5 \pm 0.4 \mathrm{~h}$ & $15-20$ & - \\
\hline & 6.0 & 33.0 & $1.8 \pm 0.4 \mathrm{c}$ & $5.2 \pm 0.3 \mathrm{~g}$ & $12-15$ & - \\
\hline & 8.0 & 40.0 & $1.0 \pm 0.3 c$ & $2.5 \pm 0.5 \mathrm{j}$ & $12-15$ & - \\
\hline
\end{tabular}

(-) indicate no response; (+) slight callusing; (++) considerable callusing; Values represent means \pm standard error of 15 explants per treatment. Means followed by the same letters are not significantly different by Duncan's multiple Range Test at $0.05 \%$ probability level.

observed in MS with $6.0 \mu \mathrm{M}$ IBA, and in $1 / 2 \mathrm{MS}$ they were $3.8 \pm 0.4$ and $10.5 \pm 0.3 \mathrm{~cm}$, respectively with the same IBA concentration. When microshoots were educated either on MS or $1 \frac{1}{2} \mathrm{MS}$ complemented with $8.0 \mu \mathrm{M}$ IBA or NAA they produced few percentages of root. Besides, deformity and slow growth of roots were also observed at the high 
concentrations of IBA or NAA complemented both in MS and 1/2MS media. Well rooted plantlets had been transferred to small plastic pots containing soil mix (garden soil: compost: sand, $2: 1: 1$ ), maintained under humid ex vitro condition in the growth room (Fig. 1G). The plantlets acclimated better under ex vitro condition if they were maintained in growth room for 30 days before transferring them to outdoor condition. After 25 days of transplantation $98 \%$ transplanted plantlets were survived and acclimated well under ex vitro condition (Fig. $1 \mathrm{H})$.

Table 4. Effects of substrates for acclimatization of in vitro derived plantlets of A. lappa under in vivo and ex vitro condition.

\begin{tabular}{lcccc}
\hline Substrate & \multicolumn{2}{c}{ No. of Leaf } & \multicolumn{2}{c}{ Survival (\%) } \\
\cline { 2 - 5 } In vivo condition & In vivo & Ex vitro & In vivo & Ex vitro \\
\hline Garden Soil (GS) & $4.2 \pm 0.4 \mathrm{c}$ & $10.4 \pm 0.7 \mathrm{c}$ & 73.3 & 66.6 \\
GS + Sand + Compost $(2: 1: 1)$ & $7.3 \pm 0.6 \mathrm{a}$ & $15.8 \pm 0.4 \mathrm{a}$ & 100.0 & 93.3 \\
Vermicompost & $5.1 \pm 0.3 \mathrm{~b}$ & $12.3 \pm 0.2 \mathrm{~b}$ & 100.0 & 80.0 \\
\hline
\end{tabular}

Values represent means \pm standard error of 15 explants per treatment. Means followed by the same letters are not significantly different by Duncan's multiple Range Test at $0.05 \%$ probability level.

Hypocotyl and cotyledon explants of $A$. lappa produced adventitious buds directly on MS containing $4.44 \mu \mathrm{M}$ BA with $10.74 \mu \mathrm{M}$ NAA as reported by HE et al. (2006a). Shahinozzaman et al. (2013) mentioned that $2.0 \mu \mathrm{M}$ BA and $1.0 \mu \mathrm{M}$ NAA was the best formulation for direct adventitious shoot regeneration from the cotyledon of Acacia mangium. A direct adventitious shoot regeneration protocol from the leaf of Gynura procumbens was described by Azad and Amin (2018) where the best formulation was 4.0 $\mu \mathrm{M}$ BAP with $2.0 \mu \mathrm{M}$ NAA. But in the present study, among the different concentration of cytokinin alone and in combination of auxins $4.0 \mu \mathrm{M}$ BAP and $2.0 \mu \mathrm{M}$ IBA produced the maximum 87.0 and $75 \%$ direct adventitious shoot from cotyledon and leaf explants, respectively. All these studies indicate that the adventitious shoot formation is highly genotype specific. Hesami et al. (2018) reported that auxin-cytokinin ratio play an important role on direct shoot regeneration as well as morphogenic and nonmorphogenic callus induction from the seedling derived petiole segments of Ficus religiosa. This result is in agreement with the findings our study where $4.0 \mu \mathrm{M}$ BAP plus $2.0 \mu \mathrm{M}$ IBA produced highest number of adventitious shoots. Similar observation was also found in in Cassia angustifolia (Siddque et al. 2015). On the other hand, Khan et al. (2015) mentioned that 10:2 ratio of auxin and cytokinin developed only highest amount of callus for grapes.

In order to optimize of tissue culture in A. lappa, callus induction, indirect and direct regeneration were carried out through Hypocotyl and cotyledon explants described by Zebarjadi et al. (2018). In that experiment Zebarjadi reported that both cotyledon and hypocotyl produced the maximum callus on a media containing $9.05 \mu \mathrm{M} 2,4-\mathrm{D}$ plus 4.44 $\mu \mathrm{M}$ BAP. The highest percentage of indirect regeneration were mentioned at $4.44 \mu \mathrm{M}$ BAP plus $2.69 \mu \mathrm{M}$ NAA on calli from hypocotyl. The highest percentage of direct 
regeneration (90.33) were also reported in hypocotyl with a lateral bud explant on MS supplemented with $2.22 \mu \mathrm{M}$ BAP plus $10.74 \mu \mathrm{M}$ NAA. HE et al. (2006b) also reported that a direct adventitious shoot regeneration occurred from hypocotyl explants on MS containing $4.44 \mu \mathrm{M}$ BA with $5.37 \mu \mathrm{M}$ NAA. Our study revealed that MS and 4.0 $\mu \mathrm{M}$ BAP with $2.0 \mu \mathrm{M}$ IBA was the most suitable combination for direct adventitious shoot regeneration from cotyledon and leaf explants. Moreover, cotyledon was the best for direct shoot regeneration than leaf explant.

Zarinjoei et al. (2014) reported that cotyledon-derived callus of Gleditsia capsica produced high frequency of shoot on MS containing only $4.4 \mu \mathrm{M}$ BA. Ning and Bao (2007) noted that half strength of MS with $22.0 \mu \mathrm{M}$ BA and $2.7 \mu \mathrm{M}$ NAA was the best formulation for plant regeneration from cotyledon-derived callus of Prunus mume. In Stevia rebaudiana, leaf explants formed high frequency of callus in MS containing $2.22 \mu \mathrm{M}$ BAP with $11.31 \mu \mathrm{M} 2,4-\mathrm{D}$. whereas, maximum number of shoots were developed on the same medium supplemented with $4.44 \mu \mathrm{M}$ BAP and $1.34 \mu \mathrm{M}$ NAA reported by Janarthanam et al. (2009). On the other hand, Ahmad et al. (2010) reported that highest percentage of adventitious shoot developed from leaf-derived callus of Ruta graveolens in MS fortified with $7.5 \mu \mathrm{M}$ BA and 1.0 $\mu \mathrm{M}$ NAA. Previous reports of different species have indicated that callus production and simultaneously plantlets regeneration from cotyledon and leaf-derived callus shows that MS as well as different types and concentrations of cytokinins and auxins are more suitable for the induction of adventitious shoots (Chand and Singh 2004). Our study revealed that MS with $4.0 \mu \mathrm{M}$

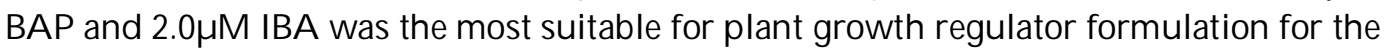
adventitious shoot development from cotyledon and leaf-derived callus. Percentage of root initiation, number of roots per shoot, root length, and root construction date were obviously prejudiced by the concentrations, types of auxins, and basal medium. Among the different absorptions of IBA, NAA or IAA complemented MS tested, rooting response of microshoots in IBA comprising medium was better than that in NAA comprising medium, while least rooting response was seen with all IAA concentrations tested. The findings are in agreement with those observed in Ruta graveolens (Ahmad et al. 2010), Citrulus lanatus (Khatun et al. 2010), Passiflora foetida (Shekhawat et al. 2015) and other plant species as well. Our experimentations exposed that among the two strength of MS media, MS showed better rooting than $1 / 2$ MS. Janarthanam et al. (2009), Chand and Singh (2004), Zarinjoei et al. (2014), Cheruvathur et al. (2010), Jaiswal and Amin (1987) and Niraula and Rajbhandary (1988) described that root obtained in 1/2MS with IBA in different mixtures were satisfactorily better than that in MS from the multiplied shoots of Stevia rebaudiana, Pterocarpus marsupium, Gleditsia capsica, Caesalpinia bonduc, Psidium guajava and Poncirus trifoliata, respectively. Cheruvathur et al. (2010) also found that extreme frequency of culture that produced roots was $100 \%$ when the shoots of Caesalpinia bonduc were cultured on $1 / 2 \mathrm{MS}$ with $6.0 \mathrm{mg} / \mathrm{IBA}$. The survival rate of in vitro plantlets and their growth depends on many conditions of external environments. The excess media was dressed from the roots and therefore the plants were transplanted in a 
satisfactory substrate like garden soil, garden-soil:sand:compost (2:1:1), and vermicompost. Firstly, plantlets were allowed to grow in in vivo (in culture room) conditions for one month. The highest $100 \%$ plantlets survive and acclimatized on garden-soil:sand:compost and vermicompost where the number of leave were 6 and 5, respectively. On the other hand, lowest $70 \%$ survival rate of acclimatization was found in only garden soil transplanted plantlets. After in vivo acclimatization plantlets were then transplanted under ex vitro condition. In outdoor condition plantlets grew up for two months and data were recoded. Highest $93.3 \%$ plantlets survived which were grown up on garden-soil:sand:compost in in vivo condition, whereas, $80 \%$ and $66.6 \%$ plantlets were survived which were primarily acclimatized on vermicompost and garden-soil, respectively (Table 4). In this experiments it was revealed that garden-soil:sand:compost was the best substrate for primary acclimatization. These studies showed that increases of plant growth at garden-soil: sand: compost in the potting medium could probably be due to improvement in the physico-chemical properties of the container medium, increase in enzymatic activity, increases in microbial diversity and activity, nutritional factors and plant growth regulators (Atiyeh et al., 2000; Azad and Amin, 2018; Arancon et al., 2004). Results obtained from this experiment revealed that growth parameters such as survival rate and number of leaves were significantly affected by applying sand and compost. Mishra et al. (2005) showed that vermicompost had beneficial effects on growth and yield of rice, especially caused significant increase of many growth parameters, seeds germination, chlorophyll concentration and yield. Similar results were reported by Najar et al. (2015), who mentioned that brinjal plant growth and yields in field soils amended with compost were significantly greater than those in the untreated plots. Plantlets were preserved during a confined environment temporarily before they will be adapted progressively in typical environment within drier air, high candlepower and temperature variations.

\section{Acknowledgements}

The authors like to thank to Ministry of Science and Technology, Bangladesh for their moral and financial support [allocation number: 9.00.0000.009.06.024.19/BS231/247]. The authors also like to thank their colleagues from the Department of Botany, Rajshahi University for their constant assistance and co-operations.

\section{References}

Ahmad N, Faisal M, Anis M and Aref IM (2010). In vitro callus induction and plant regeneration from leaf explants of Ruta graveolens L. South African J. of Bot. 76: 597-600.

Arancon, NQ, Edwards CA, Atiyeh RM and Metzger TD (2004). Effect of vermicompost produced from food waste on the growth and yields of greenhouse peppers. Bioresour. Technol. 93: 139144 . 
Atiyeh RM, Dominguez J, Sulber S and Edwards CA (2000b). Change in biochemical properties of cow manure during processing by earthworms (Eisenia andrei. Bouche) and the effects on seedling growth. Pedobiologia. 44: 709-724.

Azad MAK and Amin MN (2018). In vitro propagation and ex vitro establishment of a medicinal plant- gynura procumbens (Lour.) Merr. through leaf culture. I. J. of Advanced Res. in Bot. 4(1): 19-28.

Chan Y-S, Cheng L-N, Wu J-H, Chan E, Kwan Y-W, Lee SM-Y, Leung GP-H, Yu PH-F and Chan S-W (2010). A review of the pharmacological effects of Arctium lappa (burdock)". Inflammopharmacology. Vol. 19 (5): 245-54.

Chand S and Singh AK (2004). In vitro shoot regeneration from cotyledonary node explants of a multipurpose leguminous tree, Pterocarpus marsupium Roxb. In Vitro Cell. Dev. Biol.-Plant. Vol. 40: 464-466.

Cheruvathur MK, Britto J and Thomas TD (2010). Callus induction and shoot regeneration from epicotyl explants of ethnomedicinally important Caesalpinia bonduc (L.) Roxb. Iranian J. Biotechnol. 8(4): 263-269.

Cole TCH, Su S and Hilger HH (2016). Arctium lappa-Burdock pappus bristles can cause skin irritation and burdock ophthalmia. PeerJ Preprints. 4: e1871v1https://doi.org/10.7287/peerj. preprints.1871v1

Ferracane R, Graziani G, Gallo M, Fogliano V and Ritieni A (2010). Metabolic profile of the bioactive compounds of burdock (Arctium lappa) seeds roots and leaves. J. Pharma. and Biomed. Anal. 51(2): 399-404.

Grieve M (1971). A Modern Herbal: The Medicinal, Culinary, Cosmetic and Economic Properties, Cultivation and Folk-lore of Herbs, Grasses, Fungi, Shrubs, and Trees with All Their Modern Scientific Uses 1: 143.

HE WT, Hou SW and Wang CY (2006a). Callus induction and high-frequency plant regeneration from hypocotyl and cotyledon explants of Arctium lappa L. In Vitro Cell. Dev. Biol.-Plant 42: 411-414.

HE WT, Hou SW and Wang CY (2006b). Tissue culture and high--efficiency plant regeneration of Arctium lappa. Acta Botanica Boreali-occidentalia Sinica, 01 Jan 2006, 26(2): 319-324.

Hesami M, Daneshvar MH, Yoosefzadeh-Najafabadi M, andAlizadeh M (2018). Effect of plant growth regulators on indirect shoot organogenesis of Ficus religiosa through seedling derived petiole segments. J. Genet. Eng. Biotechnol. 16: 175-180.

Imahori Y, Kitamura N, Kobayashi S, Takihara T, Ose Kand Ueda Y (2010). Changes in fructooligosaccaride composition and related enzyme activities of burdock root during lowtemperature storage. Postharvest Biol. and Technol. 55(1): 15-20.

Jaiswal VS and Amin M N (1987). In vitro propagation of Guava from shoot cultures of mature trees. J. Pant Physiol. 130: 7-12.

Janarthanam B, Gopalakrishnan M, Sai GL and Sekar T (2009). Plant regeneration from leaf derived callus of Stevia rebaudiana Bertoni. Plant Tissue Cult. and Biotech. 19(2): 133-141.

Khatun MM, Hossain MS, Khalekuzzaman M, Rownaq A and Rahman M (2010). In vitro plant regeneration from cotyledon and internode-derived callus in watermelon (Citrulus lanatus Thumb.). Int. J. Sustain. Crop Prod. 5(4): 25-29. 
Liu S, Chen K, Schliemann W and Strack D (2005). Isolation and identification of arctiin and arctigenin in leaves of burdock (Arctium lappa L.) by polyamide column chromatography in combination with HPLC-ESIMS. Phytochem. Anal. 16(2): 86-89.

Lou Z, Wang H, Lv W, Ma C, Wang Z andChen S(2010A). Assessment of antibacterial activity of fractions from burdock leaf against food-related bacteria. Food Control. 21(9): 1272-1278.

Lou Z, Wang H, Zhu S, Zhang M, Gao Y, Ma C and Wang Z(2010B). Improved extraction and identification by ultra-performance liquid chromatograph tandem mass spectrometry of phenolic compounds in burdock leaves. J. Chromatog. 1217(16): 2441-2446.

Matsumoto T, Hosono-Nishiyama K and Yamada H (2006). Antiproliferative and apoptotic effects of butyrolactone lignans from Arctium lappa on leukemic cells. Planta Med. 72(3): 276-278.

Mishra MS, Rajani K, Sahu-Sanjat K and Padhy-Rabindra N (2005). Effect of vermicomposted municipal solid wastes on growth, yield and heavy metal contents of rice (Oryza sativa). Fresenius Environ. Bull. 14: 584-590.

Najar IA and Khan AB (2015). Effect of macrophyte vermicompost on growth and productivity of brinjal (Solanum melongena) under field conditions. Int J. Recycl Org.

Ning GG and Bao MZ (2007). Plant regeneration from callus derived from immature embryo cotyledons of Prunus mume. Hort. Sci. 42(3): 744-747. 2007.

Niraula R and Rajbhandary SB (1988). In vitro propagation of trifoliate organ (Poncirus trifoliata). Nat. Conf. of Sci. Technol. p. 141-144.

Rose F (1981). The Wild Flower Key. Frederick Warne and Co. pp. 386-387.

Shahinozzaman M, Faruq MO, Ferdous MM, Azad MAK and Amin MN (2013). Direct organogenesis and plant regeneration from cotyledons of a multipurpose tree, Acacia mangium Willd. Current Trends in Biotechnol. Pharma. 7(1): 511-517.

Shekhawat MS, Kannan N, Manokari M and Ravindran CP (2015). In vitro regeneration of shoots and ex vitro rooting of an important medicinal plant Passiflora foetida L. through nodal segment cultures. J. Genet. Eng. and Biotechnol. 13(2): 209-214.

Shimizu-Sato S, Tanaka M and Mori H (2009). Auxin-cytokinin interactions in the control of shoot branching. Plant Molecular Biol. 69(4): 429-435.

Siddique I, Bukhari NAW, Perveen K and Siddiqui I (2015). Influence of Plant Growth Regulators on In Vitro Shoot Multiplication and Plantlet Formation in Cassia angustifolia Vahl. Agriculture, Agribusiness and Biotechnology • Braz. Arch. Biol. Technol. 58(5): https://doi.org/10.1590/ S1516-89132015050290

Zarinjoei F, Rahmani MS and Shabanian N (2014). In vitro plant regeneration from cotyledonderived callus cultures of leguminous tree Gleditsia caspica Desf. New Forests 45: 829-841.

Wenting H, Suiwen $\mathbf{H}$ and Chongying $\mathbf{W}$ (2006). Tissue culture and high--efficiency plant regeneration of Arctium lappa. Acta Botanica Boreali-occidentalia Sinica 26(2): 319-324.

Zebarjadi A, Kazem S,and Kahrizi D (2018). Cell dedifferentiation and multiplication of Burdock (Arctium Lappa) as a medicinal plant. Cell Mol Biol (Noisy le Grand) 64(7): 92-96. Doi: http://dx.doi.org/10.14715/cmb/2018.64.7.16 